DOI: $10.6060 / \mathrm{mhc} 190448 \mathrm{p}$

\title{
NIR Photoresponse of Perovskite Solar Cells with Titanyl Phthalocyanine
}

\author{
Vlad V. Travkin, Anton N. Fedoseev, Yury I. Sachkov, and Georgy L. Pakhomov@ \\ Institute for Physics of Microstructures of the Russian Academy of Sciences (IPM RAS), 603950 Nizhny Novgorod, Russian \\ Federation \\ ${ }^{\circledR}$ Corresponding authorE-mail:pakhomov@ipm.sci-nnov.ru,pakhomov@ipmras.ru
}

\begin{abstract}
The effect of titanyl phthalocyanine TiOPc in the methylammonium lead triiodide (MAPbI $)_{3}$ perovskite based solar cells is studied. The photovoltaic output of cells at low intensity illumination with $\lambda_{\max }=840 \mathrm{~nm}$ is greatly enhanced when using TiOPc as a NIR-absorbing hole conductor. Compared to the reference cells with a standard cuprous iodide CuI as a hole-transporting layer, the photocurrent increases by a factor of 15, so that the narrow-band power conversion efficiency (PCE) exceeds $2 \%$. It should be pointed out that the irradiation wavelength lies beyond the intrinsic absorption of $\mathrm{MAPbI}_{3}$ or any other material in the device scheme except TiOPc. The improvement is associated with the photoactivity of TiOPc molecules in the near infrared region due to the largely splitted Q-band, as confirmed by the dependence of parameters on the polymorph transition in the TiOPc films.
\end{abstract}

Keywords: Titanyl phthalocyanine, polymorph transition, NIR absorption, perovskite solar cells.

\section{Влияние фталоцианинового красителя на фотоотклик перовскитных солнечных ячеек в ближней ИК области}

\author{
В. В. Травкин, А. Н. Федосеев, Ю. И. Сачков, Г. А. Пахомов ${ }^{\circledR}$ \\ Институт физики микроструктур РАН, 603950 Нижний Новгород, Российская Федерация \\ @E-mail:pakhomov@ipm.sci-nnov.ru,pakhomov@ipmras.ru
}

\begin{abstract}
Изучено влияние фталоччинина титанила на фотовольтаичские процессы в солнечных элементах на основе трийодида метиламмония-свинца (перовскит МAPbI ). Эффективность преобразования мошности (РСЕ) в ячейках при освещении низкой интенсивности с максимумом около 840 нм резко возрастает при использовании ТіОРс в качестве дырочно-транспортного слоя. В сравнении с эталонной ячейкой, содержащей дырочнотранспортный слой йодида меди СиI, фототок увеличивается в 15 раз, так что РСЕ солнечной ячейки в узком инфракрасном диапазоне превышает $2 \%$. Следует подчеркнуть, что максимум источника освещения лежит за пределами собственного поглощения $\mathrm{MAPbI}_{3}$ или любого другого материала в схеме устройства кроме ТіОРс. Таким образом, прогресс связан с фотоактивностью молекул ТіОРс в ближнем инфракрасном диапазоне, возникающей из-за сильного расщепления $Q$-полосы, что подтверждается и зависимостью выходных параметров от полиморфного состояния пленок ТіОРс.
\end{abstract}

Ключевые слова: Фталоцианин титанила, полиморфный переход, поглощение в ближнем ИК диапазоне, перовскитные солнечные ячейки.

\section{Introduction}

Perovkite solar cells have attracted enormous attention in the last decade due to the easily achieved, but still not stabilized, power conversion efficiencies (PCE) in order of $15-20 \%$ or higher. Planar heterojunction solar cells employing the perovskite/fullerene bilayer were first reported in ref. ${ }^{[1]}$ and since then have aroused great interest among researchers in the field due to the stablizing effect of $\mathrm{C}_{60}{ }^{[2]}$ In these cells, the methylammonium lead triiodide 
$\left(\mathrm{MAPbI}_{3}\right)$ perovskite is a single, or dominant, photoabsorber which provides the photoconversion activity in the UV/visible range up to $\sim 750 \mathrm{~nm}$. At longer wavelengths the cells are optically inactive. Several approaches to enhance spectral range of perovskite-based cells are reported. So, the photoactivity of the perovskite material itself can be extended to the NIR domain by altering its chemical structure, as shown by the example of various formamidium, mixed-metal or mixed-halide derivatives. ${ }^{[3-5]}$ Alternatively, additives to the perovskite precursor solution, like soluble phthalocyanines, ${ }^{[6]}$ enhance the light absorption being incorporated in the resulting active layer and thus improve the efficiency of cells. In ref., ${ }^{[6]}$ tert-butyl substituted copper phthalocyanine not only helped to absorb the incident photons, but also inhibited the formation of unwanted voids in the perovskite structure during the film growth. Eventually, the photon-toelectron conversion diapason of the whole multilayer device can be widened by embedding functional components that are intrinsically photoactive at the wavelengths where the perovskite materials do not absorb. ${ }^{[7,8]}$

In this work we report on the photovoltaic effect in the $\mathrm{MAPbI}_{3}$-based cells ${ }^{[9]}$ irradiated with a narrow-band light source in the near infrared (NIR). In the reference cell, cuprous iodide $\mathrm{CuI}$ was used as hole transporter in conjunction with $\mathrm{MAPbI}_{3}$. The gain in the photoresponse was achieved through pairing $\mathrm{MAPbI}_{3}$ with the molecular hole-transporting layer composed of the NIR photoabsorbing dye molecules, TiOPc (titanyl phthalocyanine).

\section{Experimental}

The preparation of the multilayer cells by the vacuum deposition technique is described previously. ${ }^{[9,10]}$ The schematic of cells is shown in Figure 1. Initially, the cell with cuprous iodide $\mathrm{CuI}$ as a hole-transporting layer (HTL) were obtained following the technological concept arisen in Refs. ${ }^{[1,2,9]}$ They served further as a reference. The composition of the cells (thickness in parentheses) was: glass $/ \mathrm{ITO} / \mathrm{MoO}_{3}(3 \mathrm{~nm}) / \mathrm{CuI}(15 \mathrm{~nm}) / \mathrm{MAPbI}_{3}$ $(250 \mathrm{~nm}) / \mathrm{C} 60(35 \mathrm{~nm}) / \mathrm{BCP}(6 \mathrm{~nm}) / \mathrm{Ag}(50 \mathrm{~nm})$. Here, ITO is a double indium-tin oxide, $\mathrm{MoO}_{3}$ is a substoichiometric molybdenum trioxide, and BCP is a bathocuproine (exciton blocking layer). The active area of the cells is determined by the strip-like top electrodes and equals to $0.13 \mathrm{~cm}^{2}$.

In the next two series, a $30 \mathrm{~nm}$ thick titanyl phthalocyanine TiOPc (Aldrich, dye content $95 \%$ ) was deposited as HTL in place of $\mathrm{CuI}$. $\mathrm{An} \mathrm{MoO}_{3}$ anodic underlayer in these series was omitted

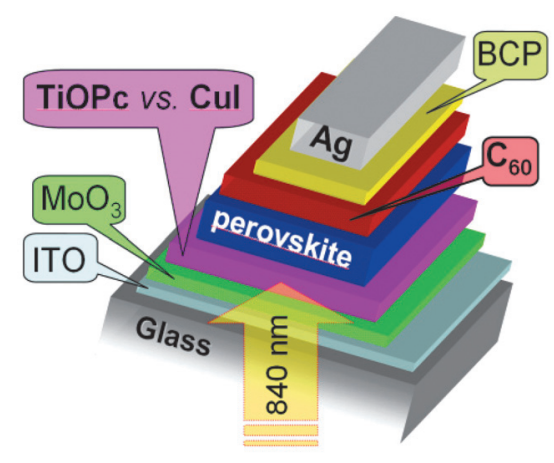

Figure 1. Schematic of photovoltaic cells fabricated and tested in this work. due to incompatibility with the molecular overlayer (very poor electrical quality of the resulting diodes). Probably, the reason lies in the pronounced disordering of TiOPc molecules in films grown on $\mathrm{MoO}_{3}$ (as described, e.g., in ref. ${ }^{[1]}$ )which makes them discontinuous. In the first series, the as-deposited TiOPc layer was used, while in the second series the molecular layer underwent thermal treatment at $150{ }^{\circ} \mathrm{C}$ during $10 \mathrm{~min}$ in air after deposition. All other experimental conditions and processes were strictly identical to those used for manufacturing and testing of the reference cells with CuI.

Photoelectrical measurements were carried out in a shielded steel chamber filled with the ultrapure argon at room temperature. A NIR LED delivering the incident light power $P_{i n}$ of $2 \mathrm{~mW} / \mathrm{cm}^{2}$ was used to irradiate the samples, its emission spectrum is shown in Figure 1. The J-V curves were taken with a Keithley SCS-4200 parameter analyzer. Note, there was no irradiation of samples in the UV and visible range, all measured photovoltaic parameters correspond to the narrow-band irradiation within the emission peak shown in Figure 1. The optical transmission of samples in the range of 360-960 $\mathrm{nm}$ was measured using a FireFly4000 spectrometer.

\section{Results and Discussion}

Figure 2(a) compares the intrinsic optical absorption of TiOPc layer on glass/ITO before and after annealing. The larger splitting of $Q$-band in annealed samples indicates the stronger aggregation of molecules in solid state. It is well-known that polycrystalline vacuum-deposited TiOPc films exist in, at least, two temperature polymorphs. ${ }^{[11-15]}$ The room-temperature polymorph is ascribed as phase I (or $\beta$ ), the high-temperature one - as phase II (or $\alpha$ ). All polymorphic modifications of TiOPc are extensively studied in the literature. The TiOPc molecule has a non-planar, convex shape with axial oxygen atom at the top (Figure S1). Monoclinic $\beta$-TiOPc can be viewed as an ensemble of alternating layers of faced Pc-rings and parallel $\mathrm{Ti}=\mathrm{O}$ bonds (TOC Figure), while in triclinic $\alpha$-phase the stacks of slipped molecules have the $\mathrm{Ti}=\mathrm{O}$ bonds oriented in opposite directions with alternating downward and upward axial ligands. ${ }^{[11,12,15]}$ The latter arrangement determines much higher photoconductivity in the $\alpha$-TiOPc crystals and thin films. ${ }^{[1,15]}$ Several groups ${ }^{[11,13]}$ reported on the beneficial effect of $\beta$-to- $\alpha$ transition on the photovoltaic parameters of the devices employing the TiOPc-based molecular heterojunctions.

In our previous work ${ }^{[9]}$ we have studied the wavelengthselective performance of the $\mathrm{MAPbI}_{3}$-based cells with cuprous iodide as HTL. An intriguing issue was the registration of a non-zero photovoltaic response under illumination at $\lambda=860 \mathrm{~nm}$, i.e., in the region where $\mathrm{MAPbI}_{3}$ layer is optically transparent (Figure 2(b)). In the entire multilayer device, some increase in absorption at wavelengthes longer than $850 \mathrm{~nm}$ is detected, its origin being non clear (probably, optical losses due to the light scattering or reflectance). In ref..$^{[5]}$ a similar effect was observed, but in the cells with a low bandgap mixed-MAPbI ${ }_{3}$ perovskite containing formamidium and tin ions, which makes it weakly absorbing up to $970 \mathrm{~nm}\left(c f .{ }^{[3]}\right)$. In this work, we repeated experiments with constructively similar devices (used as reference thereinafter) but at the decreased irradiance level of $2 \mathrm{~mW} / \mathrm{cm}^{2}$ and $\lambda=840 \mathrm{~nm}$.

Figure 3 shows the dark and NIR-illuminated J-V dependences for the cells with $\mathrm{CuI}$ or TiOPc as HTL; cor- 

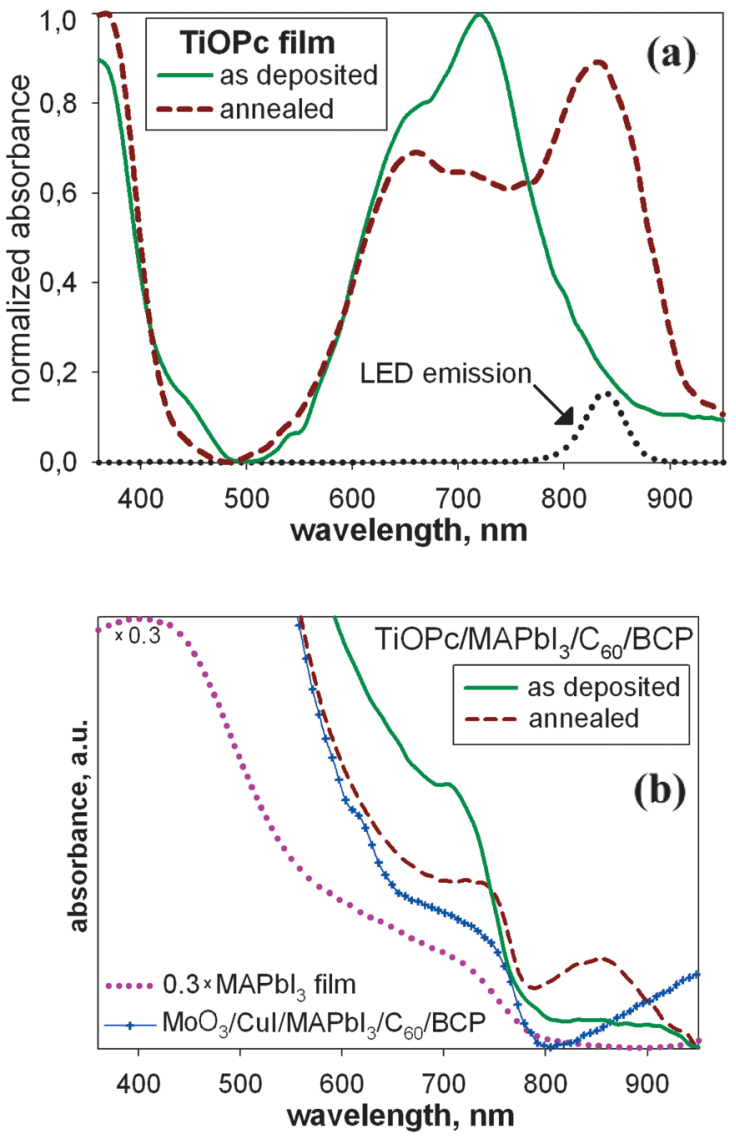

Figure 2. Absorption spectra of (a) the TiOPc films before and after annealing, the LED emission line is also shown; (b) the glass / ITO / TiOPc / $\mathrm{MAPbI}_{3}$ / C60 / BCP cell without the top Ag electrode before and after annealing of TiOPc layer, compared to the reference cell with $\mathrm{CuI}$. The absorption of the bare $\mathrm{MAPbI}_{3}$ film on glass/ITO is also given. Substrate is always subtracted.

responding parameters are summarized in Table 1. As seen from Figure 3(a), replacement of $\mathrm{CuI}$ with TiOPc decreases the density of dark currents flowing across the device under low voltages. However, when the NIR light is shed on the sample, the photovoltaic activity of the device greatly increases - Table 1, Figure 3(b). Interestingly, the photoconversion parameters do not degrade with time, as it usually occurs in the perovskite-based devices exposed to the sunlight ${ }^{[2,3]}$ (Figure 3(c)). Contrary to that, an improvement of the device efficiency is seen after $10 \mathrm{~min}$ of continuous NIR illumination, mainly owing to the contribution of the short circuit current $J_{s c}$ (Table 1). The results on illumination of samples with other narrow or wide band sources are published elsewhere ${ }^{[9]}$ (see, also, Figure S2).

To further prove whether the molecular HTL is responsible for this effect or not, we annealed the glass/ITO/TiOPc blank at $150{ }^{\circ} \mathrm{C}$ during $10 \mathrm{~min}$ before depositing the rest of the device. Figure 2(a) shows that after such a treatment the long-wavelength maximum of the split $Q$-band practically coincide with the peak external illumination, i.e., LED emission spectrum. Furthermore, this red-shifted spectral feature manifests itself very clearly in the overall absorption profile of the multilayer device - compare, Figure 2(a) and (b). As result of the increased photon cap-

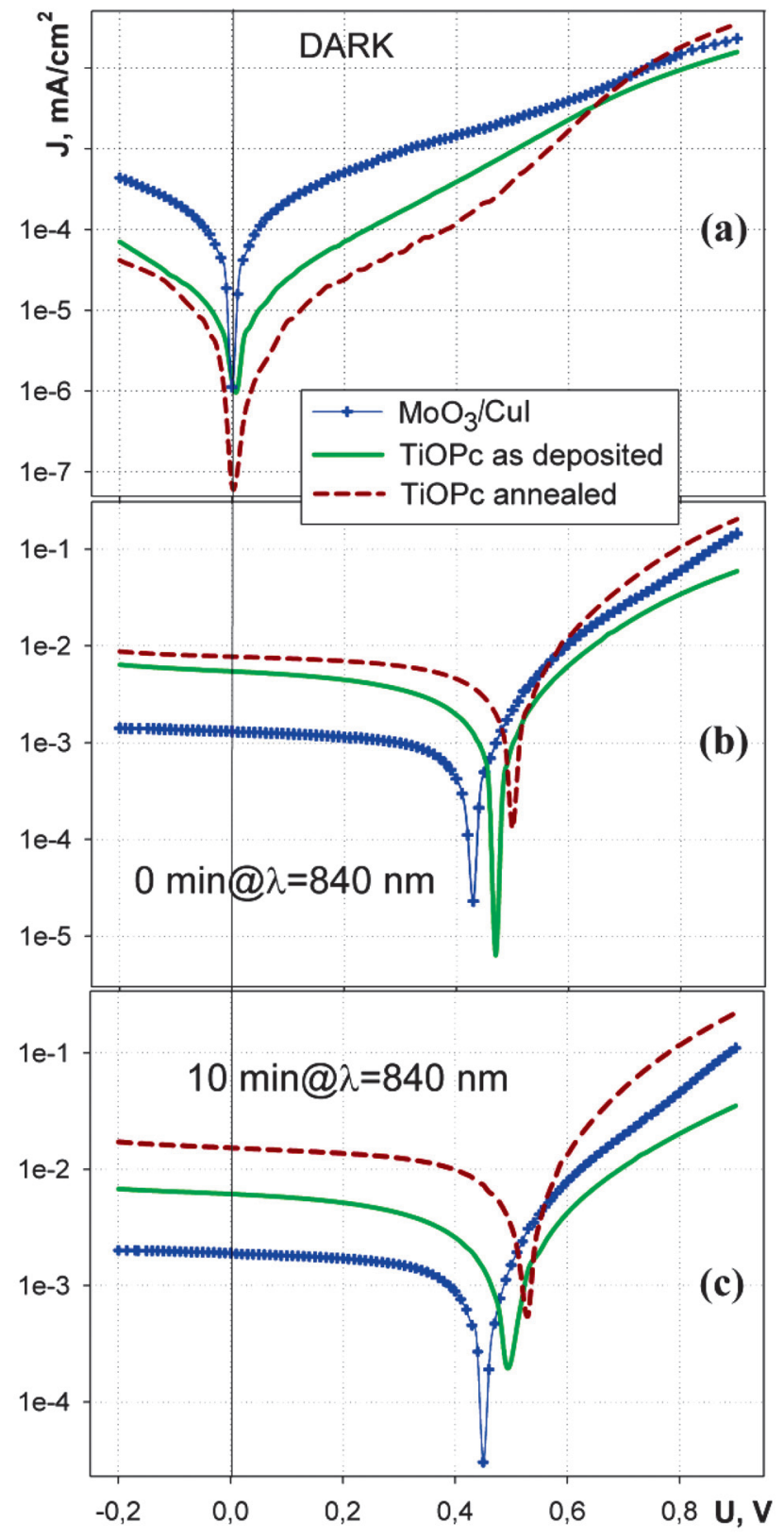

Figure 3. J-V dependences of the cells (see text).

turing in the cell, an about two-fold improvement of $P C E$ is obtained, including the increase in the fill-factor $F F$ (Table 1). The increased value of $F F$ suggests that electrical losses in the device, such as resistivity of the (molecular) layers and barrier heights, are reduced. There are several reasons that may contribute to the TiOPc annealing effect on the device performance, such as formation of $J$-aggregates or strongly coupled dimers, leading in turn to the increased hole mobility, enhanced exciton diffusion length or formation of favorable conduction passes, etc. ${ }^{[11,13,14]}$ Notably, these reasons arise solely from the molecular reorganization in TiOPc layer (see, above). At the microscopic level, this reorganization is visualized by the changes in the morphology of the TiOPc film surface (Figure S3). The tilt angle of conducting molecular stacks with respect to the substrate could also be different, depending on the deposition conditions and substrate material. ${ }^{[11,15]}$ 
Table 1. Photovoltaic parameters of the glass/ITO/HTL/MAPbI $/$ $\mathrm{C}_{60} / \mathrm{BCP} / \mathrm{Ag}$ cells at $\lambda_{\max }=840 \mathrm{~nm}\left(P_{\text {in }}=2 \mathrm{~mW} / \mathrm{cm}^{2}\right)$ measured immediately after turning the light on $(0 \mathrm{~min})$ and after continuous illumination during $10 \mathrm{~min}$.

\begin{tabular}{lcccc}
\hline \multirow{2}{*}{ Parameter } & $\begin{array}{c}\text { Illumination } \\
\text { time }\end{array}$ & \multicolumn{4}{c}{$\mathrm{HTL}$} \\
\cline { 3 - 5 } & & 0.43 & 0.47 & 0.50 \\
$\mathrm{MoO}_{3} / \mathrm{CuI}$ & $\begin{array}{c}\text { TiOPc, as } \\
\text { deposited }\end{array}$ & $\begin{array}{c}\text { TiOPc, } \\
\text { annealed }\end{array}$ \\
\hline$U_{o c}, \mathrm{~V}$ & 1 & 5 & 8 \\
$J_{s c}, \mu \mathrm{A} / \mathrm{cm}^{2}$ & $0 \mathrm{~min}$ & 0.54 & 0.41 & 0.50 \\
$\mathrm{FF}$ & & 0.15 & 0.53 & 0.97 \\
$P C E, \%$ & & 0.45 & 0.49 & 0.53 \\
\hline$U_{o c}, \mathrm{~V}$ & & 2 & 6 & 15 \\
$J_{s c}, \mu \mathrm{A} / \mathrm{cm}^{2}$ & $10 \mathrm{~min}$ & 0.54 & 0.42 & 0.50 \\
$\mathrm{FF}$ & & 0.23 & 0.63 & 2.02 \\
$P C E, \%$ & & &
\end{tabular}

Similarly to the non-annealed sample, continuous NIR illumination has a healing effect on the performance of devices with annealed HTL. After 10 min of exposure, the $J_{s c}$ value increases twice compared to the samples measured immediately after light exposure $(0 \mathrm{~min})$ (Table 1 and Figure S2). Open circuit voltage $U_{o c}$ generated by the cells rises gradually in the row $\mathrm{CuI} \rightarrow$ TiOPc initial $\rightarrow$ TiOPc annealed. This is an important point suggesting appearance, and increasing contribution, of an additional photoactive TiOPc/perovskite junction (diode), biased positively with respect to the basic perovskite/ $\mathrm{C}_{60}$ junction responsible for fundamental photovoltage in the device. ${ }^{[1]}$

\section{Conclusions}

The enhancement of spectral sensitivity of the $\mathrm{MAPbI}_{3}$ based photovoltaic cells towards the NIR range is demonstrated by introducing a non-planar phthalocyanine complex TiOPc that serves as both photoabsorber and hole-transporting layer. To the best of our knowledge, this is the first report on the efficiency $>2 \%$ in the wide bandgap $\mathrm{MAPbI}_{3}$-based solar cells at the incident photon energies lower than $1.5 \mathrm{eV}$. The effect was proved by the temperature induced polymorph transition in TiOPc. Annealing of molecular TiOPc layer induces formation to an $\alpha$-polymorph, which differs by the intensive absorption in near infrared. Photovoltaic output of the cells increases accordingly. The results are potentially interesting in view of interfacing perovskite materials with the $p$-type molecular photoabsorbers, alternatively or supplementary to the well-known perovskite/n$\mathrm{C}_{60}$ junctions.
Acknowledgements. This work was supported by RSF grant \#17-79-10397.

Author contribution statements. V.V.T. fabricated the samples and performed the electrical experiments; A.N.F. carried out spectral measurements and contributed to the calculation of photovoltaic parameters; Yu.I.S. carried out microscopic measurements and processed the data; G.L.P. aided in interpreting the results and worked on the manuscript.

\section{References}

1. a) Chiang Y.F., Jeng J.Y., Lee M.H., Peng S.R., Chen P., Guo T.F., Wen T.C., Hsu Y.J., Hsu C.M. Phys. Chem. Chem. Phys. 2014, 16, 6033-6040; b) Jeng J.Y., Chiang Y.F., Lee M.H., Peng S.R., Guo T.F., Chen P., Wen T.C. Adv. Mater. 2013, 25, 3727-3732.

2. a) Wu Z., Song T., Sun B. ChemNanoMat 2016, 3, 75-88; b) Fang Y., Bi C., Wang D., Huang J. ACS Energy Lett. 2017, 2, 782-794.

3. Ng C.H., Lim H.N., Hayase S., Zainal Z., Huang N.M. Renew. Sust. Energ. Rev. 2018, 90, 248-274.

4. a) Koh T.M., Fu K., Fang Y., Chen S., Sum T.C., Mathews N., Mhaisalkar S.G., Boix P.P., Baikie T. J. Phys. Chem. C 2013, 118, 16458-16462; b) Yu B.H., Cheng Y., Li M., Tsang S.W., So F. ACS Appl. Mater. Interfaces 2018, 10, 1592015925.

5. Xu X., Chueh C.C., Jing P., Yang Z., Shi X., Zhao T., Lin L.Y., Jen A.K.Y. Adv. Funct. Mater. 2017, 27, 1701053.

6. Wu S., Liu Q., Zheng Y., Li R., Peng T. J. Power Sources 2017, 359, 303-310.

7. Choi H., Park S., Paek S., Ekanayake P., Nazeeruddin M.K., Ko J. J. Mater. Chem. A 2014, 2, 19136-19140.

8. Meng F.L., Wu J.J., Zhao E.F., Zheng Y.Z., Huang M.L., Dai L.M., Tao X., Chen J.F. Nanoscale 2017, 9, 18535-18545.

9. Travkin V.V., Yunin P.A., Fedoseev A.N., Okhapkin A.I., Sachkov Y.I., Pakhomov G.L. J. Power Sources, submitted.

10. Drozdov M.N., Yunin P.A., Travkin V.V., Koptyaev A.I., Pakhomov G.L. Adv. Mater. Interfaces 2019. DOI: 10.1002/ admi1900364, in press.

11. Vasseur K., Rand B.P., Cheyns D., Temst K., Froyen L., Heremans P. J. Phys. Chem. Lett. 2012, 3, 2395-2400.

12. Norton J.E., Bredas J.L. J. Chem. Phys. 2008, 128, 034701.

13. a) Wang W., Placencia D., Armstrong N.R. Org. Electron. 2011, 12, 383-393; b) Placencia D., Wang W., Shallcross R.C., Nebesny K.W., Brumbach M., Armstrong N.R. Adv. Funct. Mater. 2009, 19, 1913-1921.

14. El-Nahass M.M., Afify H.A., Gadallah A.S., Hassanien A.M., Atta Khedr M. Mater. Sci. Semicond. Process. 2014, 27, 254-260.

15. Coppede N., Bonnini E., Mezzadri F., Tarabella G., Ranzieri P., Barba L., Arrighetti G., Lutterotti L., Iannotta S. Org. Electron. 2016, 32, 15-20. 